\title{
Morphological and molecular identification of hairtail (Trichiurus spp.) caught in Pangandaran Waters
}

\author{
Tia Aprianti Lestari, Murwantoko Murwantoko, Eko Setyobudi* \\ Fisheries Department, Faculty of Agriculture Universitas Gadjah Mada, Jl. Flora, Building A-4 \\ Bulaksumur, Yogyakarta, Indonesia
}

\begin{abstract}
This study aimed to identify the species of hairtail caught in Pengandaran waters based on morphological, meristic character and molecular approach. In total 135 fish samples were collected from Pangandaran Waters, during March-April 2017. Each sample was identified, measured on 22 morphometric and 4 meristic characters, then analyzed using Principal Component Analysis (PCA). Molecular identification was conducted by sequenced of 16S rRNA gene. The result of the research showed that hairtail characterized by III spines and 125-140 soft rays of dorsal fin (D.III, 125-140), the anal fin situated below 38th to 41th of dorsal-fin soft ray, I spine and 10 soft rays of pectoral fin (P.I.10), and I spine and 91 to 112 spinules of anal fin (A.I.91-112). Based on the morphological identification, the hairtail was belonged to Trichiurus lepturus. Principal Component Analysis showing the morphometric variation was presented in the caudal peduncle length. Molecular analysis of mitochondrial DNA of the partial 16S rRNA gene confirmed the hairtail as T. lepturus with similarity $98-99 \%$ based on previously published data. Phylogenetic analysis showed that T. lepturus from Pangandaran were closely similar to related species caught from the Southern Coast of Yogyakarta Special Territory (Indian Ocean) and Hainan China (Pacific Ocean).
\end{abstract}

\section{Introduction}

Hairtail, a fish species belonging to Trichiuridae family, is characterized by the long and slim body with the elongated ribbon-shaped tail fin, wide mouth, longer lower jaw than the upper contains sharp and strong long pointed fang-like teeth. The Trichiuridae distributed throughout tropical and sub-tropic regions, such as the Atlantic Ocean, the west part of Indian Ocean, North Pacific, Indo-West Pacific, Australia, Red Sea, and the South China Sea, mainly at depths of 50-1500 m, though some can be found at $2000 \mathrm{~m}$ [1]. Several species of Trichiuridae found at the depth of 20-200 m are Eupleurogrammus, Lepturachantus, and Tentoriceps, while most of the genus Assurger, Evoxymetopon, Lepidopus, Trichiurus,

* Corresponding author: setyobudi_dja@ugm.ac.id 
Aphanopus, and Benthodesmus are limited at 100-500 $\mathrm{m}$ in the edge of the continental shelf and upper part of continental slope [1]. Trichiuridae is mostly well-adapt in benthopelagic. To date, there are 17 species belong to the genus Trichiurus reported in various literature, however, only 9 species were classified as 'valid species' [2]. There are six species of Trichiurus genus that have been found in Indonesian waters namely Trichiurus haumela, $T$. glossodon, T. muticus, T. auriga, T. savala and T. lepturus [3]. Based on morphological and molecular analysis, there are only two species i.e. T. lepturus and T. brevis were found at the Indian Ocean Southern coast of East Java [4]. T. lepturus has a very broad geographical distribution, covers tropical and temperate waters throughout the world. Trichiurus taxonomy is remaining undetermined clearly due to their similarity in body shape and coloration. The identification of fish species can be conducted using morphometric and meristic characters. These characters can be used to distinguish several fish species [5], and to determine new species [6][7]. Nevertheless, fish morphology was varied due to environmental factors, growth stages, as well as fish development which caused difficulties in their identification. Recently, molecular approaches have been introduced for accurate fish identification. This method can be used to identify genetic diversity among several closely related species living in different geographic locations [8]. Taxonomy status and phylogenetic relationship were considered as important information which is necessary to facilitate the determination priority for fisheries resources conservation.

\section{Materials and Methods}

In total 135 fish samples were collected from Pangandaran Waters (West Java), during March-April 2017. Morphological identification was conducted to 135 fish samples, then 3 selected fishes were identified molecularly, respectively. Hairtail's gill was preserved in $70 \%$ alcohol before molecular analysis. Isolation and PCR analysis were conducted in the Laboratory of Fish Disease, Department of Fisheries, Faculty of Agriculture, Gadjah Mada University

\subsection{Morphological Identification}

Morphological identification was conducted based on morphometric and meristic character determination [1] [9]. Morphometric and meristic characteristics were based on 22 morphometric and 4 meristic characteristics [6]. Morphometric characters were Total Length (TL), Dorsal fin based length (DFBL), Precaudal peduncle length (PPL), Preanal length (PAL), Caudal peduncle length (CPL), Head length (HL), Snout length (SL), Postorbital length (POL), Preopercle length (POP), Upper jaw length (UJL), Body depth at pectoral fin base (BDP), Body depth at anus (BDA), Body width at pectoral fin base (BWP), Body width at anus (BWA), Predorsal length (PDL), Longest pectoral fin ray length (LOPL), Last pectoral fin ray length (LPL), Membranous interorbital width (MIW), Bony interorbital width (BIW), Dermal eye opening (DEO), Suborbital width (SW), Post supraoccipital length (PSL), while 4 meristic character were Dorsal fin ray (DFR), Dorsal fin sof rays opposite first anal spine (DFS), Pectoral fin rays (PFR), and Anal fin ray s(AFR). Several particular morphometric characteristics were selected for inter-character ratio calculation. 


\subsection{Morphometric Analysis}

Morphometric analysis to measure morphometric character correlation and relation among the population was conducted by Principal Components Analysis (PCA). Principal Component Analysis was used to identify the variation of morphometric character between populations by classification of correlated data into several independent groups. It was used to reduce the data dimension from $p$ free variables into $k$ main components $(k<p)$ [10]. Twenty-two morphometric characters were subjected to PCA to determine the number of the main component.

\subsection{Molecular Identification}

DNA was isolated following the Genomic DNA Mini Kit (Tissue) Protocol. Primer L2510 (5'- GCC TGT TTA ACA AAA ACAT-3') and H3059 (5'-CGG TCT GAA CTC AGA TCA CGT -3') were used to amplify $16 \mathrm{~S}$ rRNA component [11]. Amplification was conducted with the following conditions: pre-denaturation at $94^{\circ} \mathrm{C}$ for 5 minutes, denaturation at $94^{\circ} \mathrm{Cfor} 30$ seconds, annealing at $55^{\circ} \mathrm{C}$ for 30 seconds, initial elongation at $72^{\circ} \mathrm{C}$ for 1 minute, and final elongation at $72^{\circ} \mathrm{C}$ for 5 minutes. The cycle was repeated 35 times [7]. The result from PCR was then fragmented using 1\% agarose gel electrophoresis, stained by FloroSafe DNA Stain, and visualized using UV trans-illuminator. Purification and nucleotide sequencing of the amplified-electrophorized DNA was conducted in 1st Base Laboratory, Singapore, through PT. Genetika Science Indonesia. Nucleotide resulted from sequencing was aligned and arranged into a phylogenetic tree using Mega 6.0 software after matched with data from GeneBank NCBI (National Center for Biotechnology Information) using BLAST (Basic Local Alignment Search Tool).

\section{Results}

\subsection{Morphological and Meristic Characters}

Hairtail found in Pangandaran had several morphological traits, such as silvery steel blue and a flat ribbon-shaped long body with the tapered tail end. The fish color turning silvery grey or change into dark grey after death, particularly in the dorsal fin. Hairtail has pale yellow transparent dorsal fin with the dark end. It has a wide mouth with a longer lower jaw than the upper, which contains sharp and strong long pointed fang-like teeth and one nostril on each side of the face. The number of soft rays of Trichiurus lepturus dorsal fin in Pangandaran has a longer range than T. lepturus in other places. There was $6.67 \%$ hairtail in Pangandaran with less than 130 dorsal-fin soft rays among all observed samples (Table 1).

Table 1. Meristic characteristics of Trichiurus lepturus

\begin{tabular}{lcccc}
\hline Meristic characteristics & $\begin{array}{c}\text { Trichiurus } \\
\text { lepturus } \\
\text { (Pangandaran) }\end{array}$ & $\begin{array}{c}\text { Trichiurus } \\
\text { lepturus } \\
\text { (Firawati } \text { et } \\
\text { al., 2017) }\end{array}$ & $\begin{array}{c}\text { Trichiurus } \\
\text { lepturus } \\
\text { (Nakamura \& } \\
\text { Parin, 1993) }\end{array}$ & $\begin{array}{c}\text { Trichiurus } \\
\text { lepturus } \\
\text { (Burhanuddin } \\
\text { et al.,2002) }\end{array}$ \\
\hline $\begin{array}{l}\text { Dorsal fin rays } \\
\begin{array}{l}\text { Dorsal fin rays opposite } \\
\text { first anal spine }\end{array}\end{array}$ & III.125-140 & III. 136-137 & III.130-135 & III.132-135 \\
Pectoral fin rays & $38-41$ & $36-37$ & $39-41$ & $37-41$ \\
Anal fin rays & I.10 & I.10 & I.11-13 & I.10-12 \\
\hline
\end{tabular}


The largest T. lepturus caught in Pangandaran was $61.5 \mathrm{~cm}$ long, while the shortest was $37.3 \mathrm{~cm}$, with an average body length of $47.70 \pm 4.59$. Morphometric characteristics of $T$. lepturus caught in Pangandaran showed in Table 2.

Table 2. Morphometric characteristics of Trichiurus lepturus caught in Pangandaran

\begin{tabular}{|c|c|c|}
\hline \multirow{2}{*}{ Morphometric Characteristics } & \multicolumn{2}{|c|}{ Trichiurus lepturus $(\mathrm{N}=135)$} \\
\hline & Range $(\mathrm{cm})$ & Mean \pm SD \\
\hline Total Length & $37.3-61.5$ & $47.70 \pm 4.59$ \\
\hline Dorsal fin based length & $31.2-49$ & $37.44 \pm 3.55$ \\
\hline Precaudal peduncle length & $34.8-55.1$ & $41.64 \pm 4.00$ \\
\hline Preanal length & $13.9-24.5$ & $17.98 \pm 1.95$ \\
\hline Caudal peduncle length & $2.091-7.807$ & $5.55 \pm 1.33$ \\
\hline Head length & $5.72-9.102$ & $6.93 \pm 0.76$ \\
\hline Snout length & $1.97-3.292$ & $2.47 \pm 0.28$ \\
\hline Postorbital length & $2.565-4.394$ & $3.39 \pm 0.40$ \\
\hline Preopercle length & $1.086-1.806$ & $1.37 \pm 0.16$ \\
\hline Upper jaw length & $2.607-4.195$ & $3.19 \pm 0.36$ \\
\hline Body depth at pectoral fin base & $2.569-4.23$ & $3.19 \pm 0.38$ \\
\hline Body depth at anus & $2.519-3.957$ & $3.09 \pm 0.33$ \\
\hline Body width at pectoral fin base & $0.679-1.193$ & $0.87 \pm 0.13$ \\
\hline Body width at anus & $0.695-1.19$ & $0.89 \pm 0.11$ \\
\hline Predorsal length & $3.778-6.176$ & $4.7 \pm 0.52$ \\
\hline Longest pectoral fin ray length & $1.806-3.156$ & $2.30 \pm 0.23$ \\
\hline Last pectoral fin ray length & $0.796-1.397$ & $1.05 \pm 0.12$ \\
\hline Membranous interorbital width & $1.223-2.081$ & $1.63 \pm 0.18$ \\
\hline Bony interorbital width & $0.67-1.147$ & $0.86 \pm 0.10$ \\
\hline Dermal eye opening & $1.024-1.661$ & $1.26 \pm 0.13$ \\
\hline Suborbital width & $0.625-1.114$ & $0.80 \pm 0.10$ \\
\hline Post supra occipital length & $0.782-1.94$ & $1.05 \pm 0.16$ \\
\hline
\end{tabular}

Morphometric characteristics analysis by PCA generated three positive and negative main components. Derived from 22 characteristics, three main components were able to describe $90.04 \%$ of the total morphometric variance. The first main component (PC 1) was positive for all variables (Table 3). A higher value than 0.1 indicated that all analyzed morphometric characteristics were affected by fish size. 
Table 3. Morphometric characteristics of Trichiurus lepturus caught in Pangandaran obtained using Principal Component Analysis (PCA)

\begin{tabular}{lccc}
\hline \multirow{2}{*}{\multicolumn{1}{c}{ Morphometric Characteristics }} & \multicolumn{3}{c}{ Component } \\
\cline { 2 - 4 } & 1 & 2 & 3 \\
\hline Total Length & 0.937 & 0.307 & 0.047 \\
Dorsal fin based length & 0.960 & 0.034 & -0.039 \\
Precaudal peduncle length & 0.947 & 0.054 & -0.015 \\
Preanal length & 0.982 & 0.017 & 0.021 \\
Caudal peduncle length & 0.205 & 0.938 & 0.202 \\
Head length & 0.989 & -0.056 & 0.054 \\
Snout length & 0.980 & -0.032 & 0.058 \\
Postorbital length & 0.973 & -0.003 & -0.006 \\
Preopercle length & 0.960 & -0.048 & 0.008 \\
Upper jaw length & 0.973 & -0.110 & 0.048 \\
Body depth at pectoral fin base & 0.957 & -0.007 & -0.118 \\
Body depth at anus & 0.915 & 0.106 & -0.220 \\
Body width at pectoral fin base & 0.870 & 0.108 & -0.362 \\
Body width at anus & 0.833 & 0.154 & -0.412 \\
Predorsal length & 0.969 & -0.089 & 0.096 \\
Longest pectoral fin ray length & 0.925 & -0.118 & 0.167 \\
Last pectoral fin ray length & 0.771 & -0.180 & 0.283 \\
Membranous interorbital width & 0.919 & -0.147 & 0.034 \\
Bony interorbital width & 0.946 & -0.068 & -0.062 \\
Dermal eye opening & 0.908 & -0.212 & 0.077 \\
Suborbital width & 0.931 & 0.013 & 0.026 \\
Postsupraoccipital length & 0.707 & 0.093 & 0320 \\
Eigen value & 17.984 & 1.178 & 0.648 \\
Proportion of variance (\%) & 81.744 & 5.353 & 2.947 \\
Cumulative variance (\%) & 81.744 & 87.098 & 90.044 \\
\hline
\end{tabular}

The ratio of eyes diameter to head length ratio (DEO/HL) of T. lepturus that was caught at different areas indicated similar size among one another (18\% vs $17 \%$ vs $17 \%)$. On the other hand, caudal peduncle length to head length ratio (CPL/HL) had a large difference ( $81 \%$ vs $57 \%$ vs $119 \%$ ). T. lepturus had head length 5 to 7 times bigger than eyes diameter [1]. The morphometric characteristics ratio of T. lepturus from Pangandaran (West Java) were close to those of $T$. lepturus from Muncar and Parigi (East Java) waters, except for $\mathrm{POL} / \mathrm{HL}$ and DEO/ HL values (Table 4).

Table 4. Morphometric characteristics ratio of T. lepturus found in Pangandaran, Muncar, and Prigi

\begin{tabular}{cccc}
\hline $\begin{array}{c}\text { Morphometric } \\
\text { Characteristics Ratio }\end{array}$ & $\begin{array}{c}\text { T. lepturus in } \\
\text { Pangandaran } \\
(\mathrm{N}=135)\end{array}$ & $\begin{array}{c}\text { T. lepturus in Muncar } \\
(\mathrm{N}=170)\end{array}$ & $\begin{array}{c}\text { T.lepturus in Prigi } \\
(\mathrm{N}=177)\end{array}$ \\
Mean $(\%)$ & $\begin{array}{c}\text { (Firawati } \text { et al., } 2017) \\
\text { Mean }(\%)\end{array}$ & $\begin{array}{c}\text { Firawati } \text { et al., 2017) } \\
\text { Mean(\%) }\end{array}$ \\
\hline DFBL/TL & 79 & 80 & 75 \\
CPL/TL & 12 & 9 & 16 \\
CPL/HL & 81 & 57 & 119 \\
SL/HL & 36 & 43 & 33 \\
POL/HL & 20 & 27 & 24 \\
PDL/HL & 68 & 69 & 65 \\
DEO/HL & 18 & 17 & 17 \\
\hline
\end{tabular}


Based on morphological identification which supported by morphometric and meristic characteristics, the hairtail caught at Pangandaran was classified as Trichiurus lepturus. Hairtail identification to species level based on the method previously applied [1] was presented below (Table 5).

Table 5. The procedure of hairtail species identification based on morphology

\begin{tabular}{ll}
\hline \multicolumn{1}{c}{ Structure classification } & \\
\hline Subordo: Scombroidei & - Long body \\
& - Flat body \\
Superfamily: Trichiuroidea & - Very long and flat body \\
& - No tail fin \\
Family: Trichiuridae & - Has one nostril \\
& - No tail fin or with tail in a hair-like thin pointed shape \\
& - No pelvic fin \\
& - Concaved sub operculum edge \\
& - Small rays of the first anal fin, shorter length than eyes \\
& - pupil \\
& - So protruding fang on the upper jaw \\
Genus: Trichiurus & - No gap in the ventral side of the lower jaw \\
Species: Trichiuruslepturus & - The front part of pectoral fin not serrated \\
& - The first anal finish located under 39-41 ${ }^{\text {stdorsal fin }}$ \\
& - Hook shaped fang \\
& - The dorsal fin has more than 130 rays \\
& - Semi-transparent or pale yellowish pectoral fin \\
& - Concaved at the bottom part of the backside of operculum \\
& - Head length 5-7 times bigger than eyes diameter \\
\hline
\end{tabular}

\subsection{Molecular Identification}

UV-visualization of PCR showed DNA band was \pm 600 bp nucleotide (Figure 1). The previous report showed that gene electrophoresis of hairtail's 16S rRNA has 600 base pair amplicon [7].

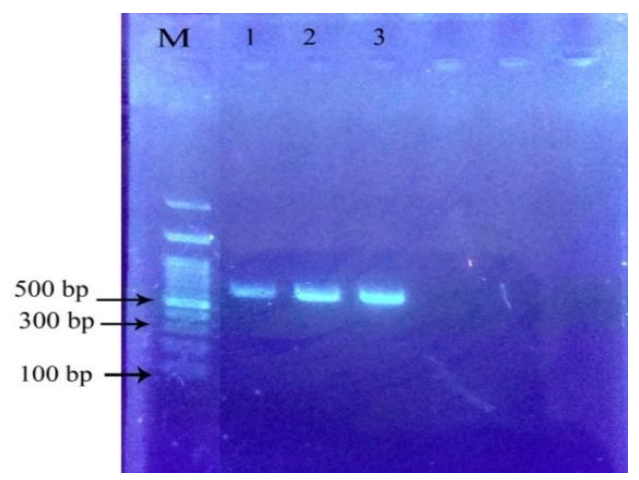

Fig. 1. PCR result of hairtail caught in Pangandaran waters. Note: (M):DNA ladder $1 \mathrm{~kb}$; (1) hairtail sample 1 ; (2) hairtail sample 2; (3) hairtail sample 3.

The hairtail caught in Pangandaran had 99\% similarity to Trichiurus lepturus caught in Persian North Sea and Oman Bay, China's Hainan, Southwest Pacific, Arab North Sea, and 
Persian Bay (GenBank accession number of JX477078, KR824530, DQ643036, KC905133, and KC307770). The results confirmed the morphology and molecular identification that hairtail caught in Pangandaran was T. lepturus. The phylogenetic tree was constructed to explain the relationship of among T. lepturus species (Figure 2).

Table 6. BLAST identification of Trichiurus lepturus caught in Pangandaran

\begin{tabular}{ccccc}
\hline $\begin{array}{c}\text { Accession } \\
\text { Number }\end{array}$ & Species & Location & $\begin{array}{c}\text { Identical } \\
\text { base pair } \\
\text { (bp) }\end{array}$ & Percentage \\
\hline JX477078 & $\begin{array}{c}\text { Trichiurus lepturus } \\
\text { nanhaensis }\end{array}$ & Hainan, China & $573 / 579$ & $99 \%$ \\
KR824530 & Trichiurus lepturus & Arab North Sea & $556 / 563$ & $99 \%$ \\
DQ643036 & Trichiurus lepturus & $\begin{array}{c}\text { Southwest Pacific } \\
\text { Persian North Seaand Oman }\end{array}$ & $546 / 547$ & $99 \%$ \\
KC905133 & Trichiurus lepturus & $550 / 555$ & $99 \%$ \\
& Bay & $549 / 555$ & $99 \%$ \\
KC307770 & Trichiurus lepturus & Persian Bay & $486 / 497$ & $98 \%$ \\
AB212883 & Trichiurus lepturus & West coast of Africa & $516 / 585$ & $88 \%$ \\
AP012508 & Assurger anzac & Japan & & \\
\hline
\end{tabular}

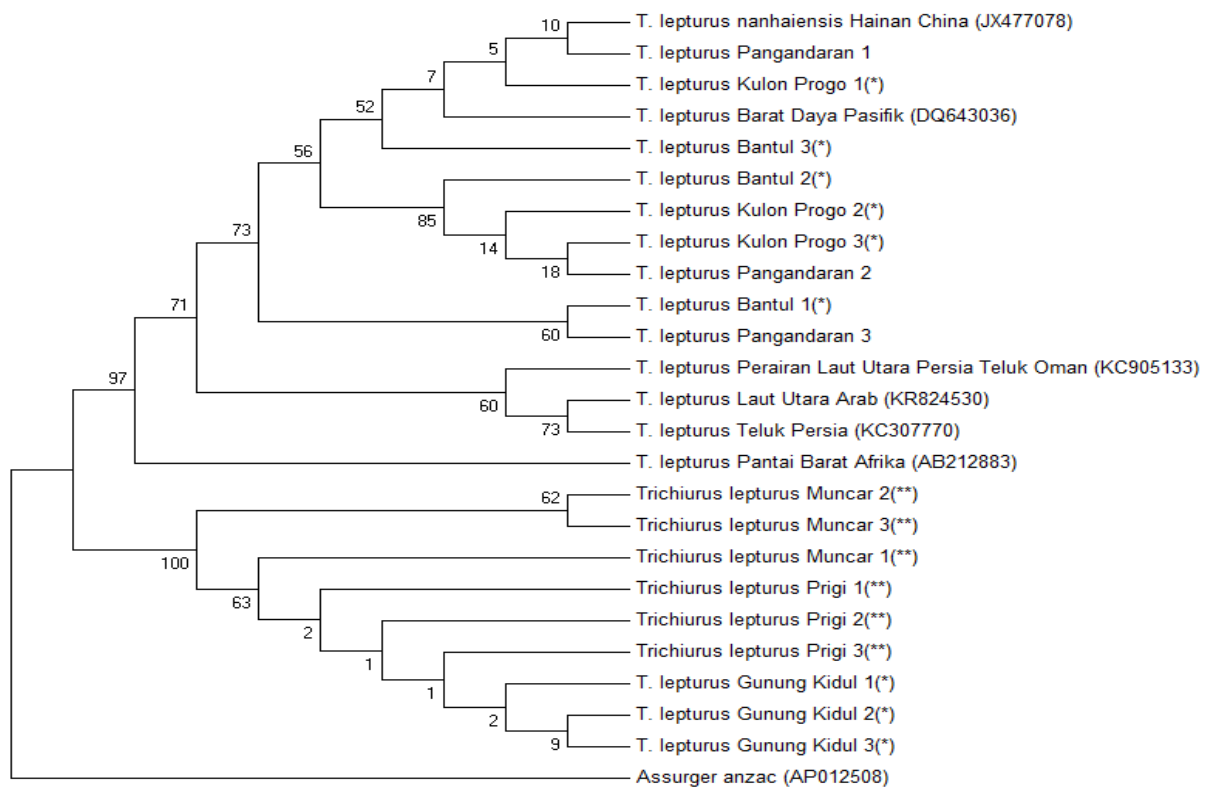

Note: (*) personal communication; (**) Firawati et al. (2017)

Fig. 2. Phylogram of Trichiurus lepturus caught in Pangandaran obtained using maximum likelihood method

\section{Discussion}

Morphological identification showed that T. lepturus had particular characters distinctive to other hairtail species. Supraorcipital crest position of T. lepturus is vertically located far behind eye circle posterior, distinctive to that of $T$. russeli and $T$. brevis which located just behind eye circle posterior part. T. lepturus had shorter precaudal peduncle length and longer 
caudal peduncle length than $T$. russeli and T. brevis [9]. T. lepturus also can be identified by the longer space between eye circle edge and first dorsal fin position than T.australis, $T$. russeli, and T. brevis (127\%-129\% compare to $74 \%, 75 \%$, and $75 \%$ of eyes diameter, respectively) [7]. The front part of the pectoral fin of both T. auriga and T. lepturus is not sharply serrated, while $T$. gangeticus has it otherwise. T. lepturus and T. gangeticus have 2 or 3 pairs of the big and sharp hook-shaped fang on the upper and lower jaw [1].

Based on the principal component analysis (PCA), distinguishing characters to differentiate Pangandaran's hairtail were caudal peduncle and parts around the body. The previous study reported that the characteristics to differentiate T. lepturus from T. brevis in Prigi and Muncar were located in the head and tail [4]. Moreover, the discriminant analysis showed that meristic characteristics of upper jaw length and caudal peduncle length can also be used. Fish was more likely to have higher morphology variations in a population or among different population compared to other vertebrates, since its phenotype can be changed due to environmental factors, such as salinity, temperature, and feed availability [12]. Significant morphology, meristic, and genetic difference among stock or population in a species can also be caused by geographical isolation thus inhibit genetical flow among populations [13]. Changes in nucleotide as DNA compiler is also another reason for genetic diversity, which might affect the phenotype of a particular organism or individual reaction toward the environment. Genetic diversity can be triggered by mutation, recombination, or gene migration from one place to another [14].

Phylogram of T. lepturus caught in Pangandaran (Figure 3) indicated that it has a close relation to T. lepturus living in Kulon Progo and Bantul (Yogyakarta Special Territory), which arguably caused by close geographical habitat hence genetic flow among aquatic regions. Interestingly, Pangandaran's T. lepturus was also closely related to the species living in the distance geographical regions of Hainan, China, and the southwest Pacific. Wide range hairtail distribution and close relation to the same species living in distance location might be caused by different migration patterns. Migration is affected by internal and external factors. Metabolic balance and feed driven migration are part of internal factors [15]. Hairtail migration can also occur during the spawning season. Female T. lepturus stay around the continental shelf in southern Brasil during winter for feed hunting, the male migrates to the warmer northern region or offshore [16]. Hairtail distribution in Aru Sea was reportedly caused by seasonal change due to migration-related fish abundance during winter and by spawning [17]. The external factor which affects hairtail distribution was sea current with an important role in fish larvae dissemination. Sea current affects population distribution and changes water characteristics which in turn determine organism physiology and genetic structure [18].

Based on morphological identification, hairtail caught in Pangandaran was Trichiurus lepturus, characterized by III.125-140 dorsal fin and anal fin position that aligned with soft rays of 38-41 dorsal fin, I.10 pectoral fin, and I.91-I.112 anal fin. PCA analysis indicated that morphological variance was in caudal peduncle length by which hairtail formed one population. Molecular identification using mitochondrial 16S rRNA confirmed the morphological identification as T. lepturus. Phylogenetic analysis showed that T. lepturus from Pangandaran were closely similar with related species caught from Southern Coast of Yogyakarta Special Territory (Indian Ocean) and Hainan China (Pacific Ocean).

\section{References}

1. I. Nakamura, N.V. Parin.Snake Mackerels and Cutlassfishes of The World. FAO Species Catalogue 125, 15 (1993) 
2. K.C. Hsu, N. T. Shih, I. H. Ni, K. W. Shao. Speciation and Population Structure of Three Trichiurus Species Based on Mitochondrial DNA. Zoological Studies 48, 6: 835-849 (2009)

3. K.E. Carpenter, V.H. Niem. FAO Species Identification Guide for Fishery Purpose. The Living Marine Resources of The Western Central Pacific. Volume 6. Food Agriculture Organization of United Nation, Mexico. (2001)

4. I. Firawati, Murwantoko, E. Setyobudi. Morphological and Molecular Characterization of Hairtail (Trichiurus spp.) from the Indian Ocean, Southern Coast of East Java, Indonesia. Biodiversitas 1, 18: 190-196 (2017)

5. K. Yokogawa, S. Seki. Morphological and genetic differences between Japanese and Chinese Sea Bass of the Genus Lateolabrax. Japan J Ichthyol 41: 437-445 (1995)

6. A.I. Burhanuddin, Y. Iwatsuki. Trichiurus nickolensis, A New Hairtail From Australia Belonging the Trichiurus russelli complex (perciformes: trichiuridae). Ichthyological Research 50: 270-275 (2003)

7. A. Chakraborty, A.I. Burhanuddin, Y. Iwatsuki. A new species,Trichiurus australis (Perciformes: Trichiuridae), from Australia. Ichthyol Res 52: 165-170 (2005)

8. A. Chakraborty, Y. Iwatsuki Y. Genetic variation at the mitochondrial 16S rRNA gene among Trichiurus lepturus (Teleostei: Trichiuridae) from various localities: preliminary evidence of a new species from West coast of Africa. Hydrobiologia 563: 501-513 (2006)

9. A.I. Burhanuddin, Y. Iwatsuki, T. Yoshino, S. Kimura. Small and Valid Species of Trichiurus brevis Wang and You, 1992 and T. russelli Dutt and Thankam, 1966, defined as the "T. russelli complex" (Perciformes: Trichiuridae). Ichthyological Research 49: 211-223 (2002)

10. S. Landau, B.S. Everit. A Handbook of Statistical Analyses Using SPSS Chapman and Hall/CRC Press Company. New York. (2004)

11. M. Miya, M. Nishida. Molecular Phylogenetic Perspective on The Evolution of The Deep-Sea Fish Genus Cyclothone (Stomiiformes: Gonostomatidae). Ichthyological Research 43(4): 375-398 (1996)

12. C. Turan, M. Oral, B. Ozturk, and E. Duzgunes. Morphometric and Meristic Variation Between Stock of Bluefish (Pomatomus saltatrik) in The Black, Marmara, Aegean, and Northeastern Mediterranean Seas. Journal Fisheries Research 79: 139-147 (2006)

13. C. Turan. Stock identification of Mediterranean Horse Mackerel (Trachurus mediterraneus) Using Morphometric and Meristic Characters. Journal of Marine Science 61: 774-781 (2004)

14. D.A. Rahayu, E.D. Nugroho. Biologi Molekuler dalam Perspektif Konservasi. Plantaxia, Yogyakarta. (2015)

15. A. Zamroni, Suwarso, E. Nugroho. Struktur Genetika Populasi Ikan Malalugis Biru (Decapterus macarellus Cuvier, 1833) di Sekitar Sulawesi Berdasarkan Mt-DNA Marker. Jurnal Penelitian Perikanan Indonesia 1(20): 31-41 (2014)

16. A.S. Martins, M. Haimovici. Reproduction of The Cutlassfish Trichiurus lepturus in The Southern Brazil Subtropical Convergence Ecosystem. Scientia Marina 64(1): 97105 (2000)

17. C. H. Cheng, T. Kawasaki, K.P. Chiang, C.H. Ho. Estimated Distribution and Movement of Hairtail Trichiurus lepturus in the Aru Sea, Based on The Logbook Records of Trawlers. Fisheries Science 67: 3-13 (2001) 
18. B. Gaylord, S. D. Gaines. Temperature or Transport? Range Limits in Marine Species Mediated Solely by Flow. American Naturalist 6 (155): 769-789 (2000) 